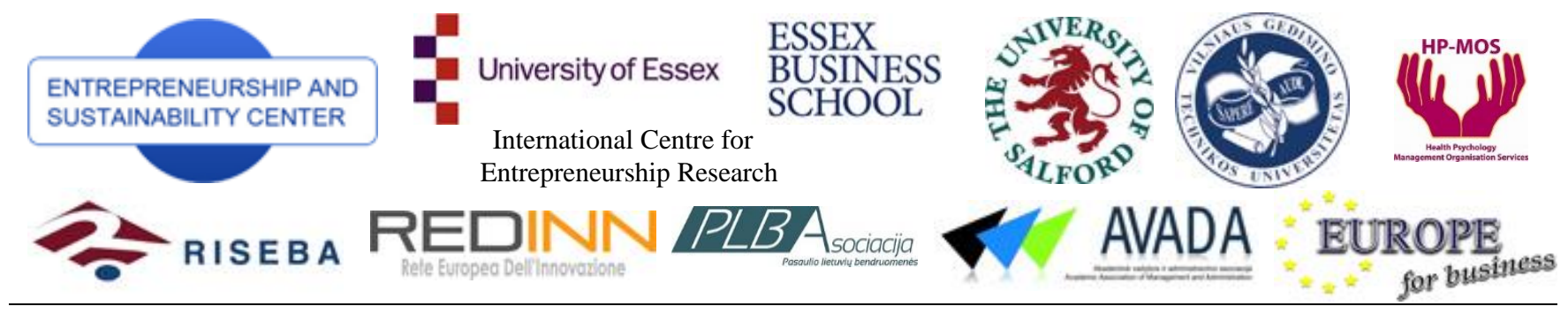

ENTREPRENEURSHIP AND SUSTAINABILITY ISSUES

ISSN 2345-0282 (online) http://jssidoi.org/jesi/

\title{
THE MANAGEMENT BY OBJECTIVES IN BANKS: THE POLISH CASE
}

\author{
Jerzy Kaźmierczyk ${ }^{\text {, Mateusz Aptacy² }}$ \\ ${ }^{1}$ Poznan University of Economics and Business, address: al. Niepodlegtości 10, 61-875 Poznań, Poland, \\ Tyumen State University, address: 6 Volodarskogo St., 625003 Tyumen, Russia \\ ${ }^{2}$ Poznan University of Economics and Business, address: al. Niepodległości 10, 61-875 Poznań, Poland, \\ E-mails:' jerzy.kazmierczyk@ue.poznan.pl; ${ }^{2}$ mateusz.aptacy@gmail.com.
}

Received 15 May 2016; accepted 25 July 2016

\begin{abstract}
This paper examines the occurrence of Management by Objectives system in banks in Poland. According to the theory, MBO should be applied to the entire organization; however, in practice MBO is often used only in selected parts of the organization. The purpose of this study was to investigate the segmentation of MBO in banks, according to the job position, job seniority, educational and gender aspects individually. Firstly, grounded on the literature, this article describes the characteristics of MBO and the rewarding plans for the achievement of objectives. The survey among bank employees helped to accomplish the research aim undertaken in this article. Based on conducted research, empirical subsection shows the results of the study in comparison to the analysis made by other authors. The results revealed the diversity in using MBO in banks in Poland. Furthermore, showed that male employees in banks are covered by the Management by Objectives system more frequently than females, and that bank staff with tertiary education are subject to the Management by Objectives more often than employees with secondary education.
\end{abstract}

Keywords: HRM, management by objectives, banks, Poland

Reference to this paper should be made as follows: Kaźmierczyk, J., Aptacy, M., 2016. The management by objectives in banks; the Polish case, Entrepreneurship and Sustainability Issues 4(2): 146-158

DOI: http://dx.doi.org/10.9770/jesi.2016.4.2(3)

JEL Classifications: J2, M5, M54

\section{Introduction}

According to Olexandrivna, modern enterprises seek a balance for the functioning of all of their subsystems. This harmony has a significant influence on the strategic development of the whole organization, which in turn may result in its competitive advantage (Olexandrivna 2016, p. 63). In the contemporary scientific literature various ways to gain competitive advantage are discussed and suggested (e.g. Fuschi, Tvaronavičiené 2014; Belás et. al. 2016; Razminienè et al. 2016; Tvaronavičienè, Černevičiūtè 2015). One of the ways to achieve this balance could be the Management by Objectives (MBO). Unfortunately, in practice MBO frequently deviates significantly from 
the foundations laid by its author, P.F. Drucker. MBO has been studied for a long time, as shown by the literature review. What is missing is the current research taking into account the changing conditioning (Voronov et al., 2014, pp. 29-30; Romashkina and Andrianova, 2007, p. 50; Bondaryeva et al., 2015, pp. 236-237; Wyrwa 2015, p. 127). MBO is relatively new in Poland and there is not enough research on MBO in Poland. Theory assumes that MBO should be applied to the entire organization; however, practice has shown that MBO in Poland is often used only in selected parts of the organization.

This study focuses on the employment in banks in Poland. The banking sector is the biggest and best-developed segment of the Polish financial system. It is characterized by rapid development on the domestic market and the use of a variety of interesting human resources management tools, including MBO (Kaźmierczyk and Świt 2011, p. 299). This is due to the large share of foreign capital in Polish banking sector. Polish banks make successful use of a range of solutions adopted in Western Europe. Moreover, banks employ large staffs, which allows one to make a reliable assessment of the submitted theses.

The main aim of this paper is to present the concept of Management by Objectives and then to analyse and evaluate its occurrence in banks in Poland. This paper propounds the following theses:

1. There is segmentation of banks in Poland according to the use of the Management by Objectives system.

2. The Management by Objectives in banks more often involves the managerial staff than non-managerial employees.

3. In banks, the Management by Objectives is more common among employees with longer job seniority in the current workplace than among people at the beginning of their employment in a particular unit.

4. Bank employees with tertiary education are subject to the Management by Objectives more frequently than employees with secondary education.

5. Male employees in banks are part of the by the Management by Objectives system more frequently than females.

To accomplish the research aim undertaken in this paper, the author used specialist literature both in Polish and in English (The ACM Digital Library, BazEkon, EBSCO, Emerald, ProQuest). A survey was also used which examined nearly 2,000 bank employees.

This article consists of introduction, two theoretical subsections characterizing MBO and the rewarding plans for the achievement of objectives, the description of the research method and the empirical data, the results of the empirical study and conclusions.

\section{Management by Objectives as concept}

The Management by Objectives, also described in the specialist literature as the Management by Objectives and Self-control, was first described by P.F. Drucker in the book The Practice of Management. This concept was introduced into the practice of management in the 1960s. Initially, it was criticized due to possible negative effects that it could bring (f.ex. adverse influence on employees' creativity). It also met with disapproval because of managers' who, following the latest trends, introduced it blindly without full understanding of the basic conditions required for its application (Fulk, Bell and Bodie 2011, p. 18).

According to X. Liu definition (2010, p. 219), 'MBO is a suit of systematization democratic management style which higher-level and lower-level managers and employees in a organization together set down the common organization goal, form one goal system and specify and outspread to every department, every administrative level, every employee in organization and ties nearly up with their duty and production of every department, every administrative level, every employee within organization, definitely prescribe their consecration and encouragement.' The Management by Objectives is based on bilateral communication between 
the manager and a subordinate employee. They are both engaged in the joint process of setting objectives, which channel their collective efforts and serve as the basis for assessment. It was assumed that all employees engaged in the process of determining objectives will put more effort into their realization, which will in turn contribute to a higher probability of their accomplishment. These activities have a stimulating effect on the employees' motivation and oblige them to take responsibility for the realization of tasks in the setting of which they have participated himself. Moreover, R. Čiutienè and P. Petrauskas (2012, p. 1560) noticed that apart from setting the goals, MBO should also 'monitoring, motivating, control and awarding for each person and all organization'. Therefore, it could be an overall system conducive to the performance of the organization.

It is crucial that every manager should have the information he needs to evaluate his efficiency and that he should have the information early enough. That allows him to make changes necessary for the achievement of the desired objectives and for the functioning of the organization as a whole. It is fundamental that this information should reach the manager directly, excluding his superior, to avoid it becoming an element of Top-Down Management. Moreover, at a time when the access to databases and their analyses is practically unlimited, superiors should resist the temptation to exercise regular control over their subordinates, because by doing so they may significantly undermine employees' independence, which may result in their decreased efficiency. Obviously, all methods that the organization considers as undesirable, unethical or unprofessional, should be clearly specified. Managers must be aware which practices are considered reprehensible. For the Management by Objectives to function efficiently, managers ought to be independent during the decision process, without fracturing the system's structures (Drucker 1994, p. 151).

\section{The rewarding plan for the achievement of objectives}

The benefits company gains from the implementation of MBO are not limited only to the increased productivity but also cause the increase in employees' motivation and job satisfaction. The Management by Objectives in principle helps the workers become a real team focused on both individual and organizational goals. Many of them show interest in improving professional skills, some even undertake specialist training. The more the employees are willing to work in groups, the greater the benefits for the company as they learn their skills from each other (Luft 2014, p. 25).

It must be stressed that the Management by Objectives is effective only when it is supported by the existing motivation system. The bonus system cannot function as an autonomous incentive scheme. For the MBO system to have a proper effect on motivation, it should work separately from the existing bonus scheme. Gratifications ought to be awarded, as it were, during periodic reviews. Furthermore, when the Management by Objectives system does not bring the expected results, then an additional bonus system may not improve its effectiveness. All benefits should derive from the good results produced by the Management by Objectives, the only system solely responsible for awarding the employees. Any use of discretionary factors in the evaluation and awarding of the employees is unacceptable. It may lead to pathology in the functioning of the system (Reinfuss 2009, p. 156).

In the MBO system, excessive concentration on the tangible measurable goals and the underestimation of the abstract ones can become an obstacle to the evaluation of an employee's performance. This problem results from the SMART goal-setting criteria, according to which every objective should be e.g. measurable. In practise there are many situations, when the parameters to be achieved are difficult to determine in advance. It can be problematic to assess the quality of the transactions executed by a company, because such values as the level of trust between the parties of a contract or the employees' influence on the atmosphere in the workplace are hard to measure (Bieniok 2001, p. 171; Barska and Łychmus 2007, pp. 39-40). The Management by Objectives makes managers concentrate primarily on their own, current objectives, which directly affect their results (and consequently, the corresponding bonuses) instead of the prospective goals of the whole organization. They avoid taking a firm and clear stance on current, unpredictable issues as any wrong decision may adversely influence their bonuses and any right decision 
will not be awarded anyway. Thus, MBO may exonerate the employees from caring for the condition of the overall organization (Blikle 2014, p. 112).

\section{The main theses of the Management by Objectives system}

This paper propounds the following theses:

1. There is segmentation of banks in Poland according to the use of the Management by Objectives system.

2. The Management by Objectives in banks more often involves the managerial staff than non-managerial employees.

3. In banks, the Management by Objectives is more common among employees with longer job seniority in the current workplace than among people at the beginning of their employment in a particular unit.

4. Bank employees with tertiary education are subject to the Management by Objectives more frequently than employees with secondary education.

5. Male employees in banks are part of the by the Management by Objectives system more frequently than females.

According to G.H. Graham, it is relatively rare for non-managerial employees to work under the Management by Objectives system (Graham 1968, p. 300). This is because they have limited access to current information on the organization's condition and therefore their influence on the formulation of its objectives is also very limited. On the other hand, employees in managerial positions are included in MBO more frequently. It could be due to their greater impact on the organization's efficiency and greater responsibility for its functioning. Considering MBO's differentiation with regard to particular working positions, the following thesis was posed: the Management by Objectives in banks includes the managerial staff more frequently than non-managerial employees.

The length of service (seniority) in an organization refers to the number of years an employee has been part of a particular company. Subordinates may understand better and have more confidence in a more experienced manager. They are more efficient and more aware of their meaning for the whole organization and consequently there are fewer failures in the process of goals achievement (Lederer and Burky 1988, p. 60). Considering the nature of employment in banks, a thesis can be propounded that the Management by Objectives is more frequent for employees with a longer seniority with a present employer than those starting their job in a particular company. In addition, an employee's work experience is likely to be correlated with his position on the organizational ladder. Persons in managerial positions are more likely to have been long-term employees, a fact which favors the use of MBO.

Although the MBO system is often assumed to cover the entire organization (Chrościcki 1999), in practice it often does not prove to be so. The level of education greatly influences the success of the use of MBO. It is argued that a better-educated manager is more likely to embrace the organization in its entirety. He also has a better understanding of the objectives of individual employees (Lederer and Burky 1988, p. 60). On the other hand, the lack of certain skills may cause serious problems with cooperation (Tosi, Rizzo and Carroll 1970, p. 74). Accordingly, it can be concluded that those working under the Management by Objectives system are better-educated and have better professional qualifications, which help them find themselves better in the MBO system. A thesis therefore was propounded that employees with tertiary education are subject to the Management by Objectives more frequently than employees with secondary education.

J. Losak (1975, p. 10-11) has noticed that males are involved in the Management by Objectives more frequently than females. The source of this inequality may be the insufficient use of females' potential and it could be connected with the glass ceiling phenomenon (Baxter and Wright, 2000, pp. 275-276; Kalinowska-Sufinowicz, 2005). Employers promote males to managerial positions more frequently even if their professional skills are approximately equal to those of female employees (Omran, Alizadeh and Esmaeeli 2015, p. 316). In consequence, despite being appropriately qualified, females tend to hold lower positions (not covered by MBO) than males. 
Accordingly, a thesis was put forward that male staff in banking are covered by the Management by Objectives more frequently than female employees.

\section{Methodology 1}

The data from the survey, which was conducted from January 2016 to April 2016, were used to test the research thesis. The "snowball" technique was used in order to collect the data ${ }^{2}$. The survey participants were invited by existing subjects. Personal contacts and individual visits to banks were used to collect the data. More than 20.000 queries were sent with a request to fill in the questionnaire via e-mail, social networking websites (such as Facebook, GoldenLine and LinkedIn) and thematic forums. Both an electronic version (https://docs.google.com/forms/d/1fq9ZKdr8zXA7zjp8wFowBqJ6ciT4nSmjer598pGWbG0/viewform) and hard copy one of the questionnaire were used in the survey.

The main survey was preceded by a two-staged pilot survey. First, the survey was conducted on a small group of target participants (180 students). The aim was to reveal any inconsistencies and to examine whether the questions were understandable. Thanks to the pilot study, the questionnaire was modified and improved. In the second stage, the target group consisted of 100 employees from the banking sector.

The questionnaires have been completed by 1.949 respondents. 29 questionnaires were rejected due to low credibility and reliability (for example, some respondents selected " 0 " in response to all of the closed-ended questions). As a result, the final research sample consists of 1.920 respondents (152 electronic version and 1768 hard copy). Table 1 provides more details regarding the sample structure.

Table 1. Sample structure

\begin{tabular}{|c|c|c|c|}
\hline \multicolumn{2}{|c|}{ Criterion } & Number of individuals & Percentage \\
\hline \multirow[t]{3}{*}{ Gender } & Female & 1312 & $68.33 \%$ \\
\hline & Male & 473 & $24.64 \%$ \\
\hline & No answer & 135 & $7.03 \%$ \\
\hline \multirow[t]{7}{*}{ Education } & University (major in economics) & 883 & $45.99 \%$ \\
\hline & University (other) & 515 & $26.82 \%$ \\
\hline & High school (major in economics) & 270 & $14.06 \%$ \\
\hline & High school (other) & 189 & $9.84 \%$ \\
\hline & Vocational & 2 & $0.1 \%$ \\
\hline & Elementary & 2 & $0.1 \%$ \\
\hline & No answer & 59 & $3.1 \%$ \\
\hline \multirow[t]{5}{*}{ Occupied position } & Senior managerial position & 43 & $2.24 \%$ \\
\hline & Middle-level managerial position & 129 & $6.72 \%$ \\
\hline & Lower-level managerial position & 153 & $7.97 \%$ \\
\hline & Non-managerial position & 1485 & $77.34 \%$ \\
\hline & No answer & 110 & $5.73 \%$ \\
\hline \multirow[t]{4}{*}{ Organizational unit } & Headquarters & 409 & $21.3 \%$ \\
\hline & Regional branch & 416 & $21.66 \%$ \\
\hline & Operational branch & 1020 & $53.13 \%$ \\
\hline & No answer & 75 & $3.91 \%$ \\
\hline
\end{tabular}

\footnotetext{
${ }^{1}$ The research results presented are part of a broader study (about: recruitment, forms of employment, motivation, professional education, e-learning, loyalty, stress, work efficiency, MBO, perks, mobbing, professional career, derecruitment, dismissals and outplacement), which was based on the same research method. Thus, the description of the research method is applicable also to the results of research on other aspects of HRM and other papers by Jerzy Kaźmierczyk.

${ }^{2}$ This method does not generate high research cost. Another advantage is that it allows to reach a wider population and is relatively simple.
} 
The International Journal

ENTREPRENEURSHIP AND SUSTAINABILITY ISSUES

ISSN 2345-0282 (online) http://jssidoi.org/jesi/ 2016 Volume 4 Number 2 (December)

\begin{tabular}{|c|c|c|c|}
\hline \multirow{3}{*}{ Type of bank } & Commercial bank & 1342 & $69.90 \%$ \\
\cline { 2 - 4 } & Cooperative bank & 481 & $25.05 \%$ \\
\cline { 2 - 4 } & No answer & 97 & $5.05 \%$ \\
\hline \multirow{3}{*}{ The equity } & National & 919 & $47.86 \%$ \\
\cline { 2 - 4 } & Foreign & 863 & $44.95 \%$ \\
\cline { 2 - 4 } & No answer & 138 & $7.19 \%$ \\
\hline \multirow{3}{*}{ Workplace } & Front office & 1118 & $23.96 \%$ \\
\cline { 2 - 4 } & Back office & 460 & $17.81 \%$ \\
\cline { 2 - 4 } & No answer & 342 & $94.79 \%$ \\
\hline \multirow{3}{*}{ Disability } & Lack & 1820 & $0.63 \%$ \\
\cline { 2 - 4 } & Slight level & 12 & $0.42 \%$ \\
\cline { 2 - 4 } & Moderate level & 2 & $0.1 \%$ \\
\cline { 2 - 4 } & Significant level & 78 & $4.06 \%$ \\
\cline { 2 - 4 } & No answer & & \\
\hline
\end{tabular}

Source: own computations based on the survey data

The composition of the research sample according to gender, type of education and type of bank corresponds to the structure of employment in the banking sector in Poland (Kaźmierczyk, 2011, p. 115-124). The mean age of respondents was 36.612 years. The mean work experience in banking was 12.065 years, ranging from 1 to 43 years. The mean total work experience of respondents was 14.976 years (Table 2).

Table 2. Summary statistics on age and work experience

\begin{tabular}{|c|c|c|c|c|c|}
\hline Criterion & Minimum & Maximum & Mean & Median & Standard deviation \\
\hline Age & 19 & 64 & 36.612 & 35 & 9.7496 \\
\hline Work experience in banking & 1 & 43 & 12.065 & 10.000 & 9.5799 \\
\hline Work experience with current employer & 1 & 43 & 9.835 & 7.000 & 9.3882 \\
\hline Total work experience & 1 & 45 & 14.976 & 12.000 & 10.2416 \\
\hline
\end{tabular}

Source: own computations based on the survey data

The locality size criterion demonstrates that the largest group of respondents came from the localities inhabited by 50 thousand people, the fewest surveyed people coming from localities with 200-500 thousand inhabitants (Table $3)$.

Table 3. Summary statistics on place of residence

\begin{tabular}{|c|c|c|c|}
\hline \multirow{3}{*}{ Size of locality } & to 50 thous people & 658 & $34.27 \%$ \\
\cline { 2 - 3 } & $50-100$ thous people & 251 & $13.07 \%$ \\
\cline { 2 - 3 } & $100-200$ thous people & 245 & $12.76 \%$ \\
\cline { 2 - 3 } & $200-500$ thous people & 124 & $6.46 \%$ \\
\cline { 2 - 3 } & More than 500 thous people & 541 & $28.18 \%$ \\
\cline { 2 - 3 } & No answer & 101 & $5.26 \%$ \\
\hline
\end{tabular}

Source: own computations based on the survey data

The questionnaire consists of an introduction followed by 23 closed-ended questions and several demographic and work-related questions. The main part of the questionnaire contains questions which refer to seven important human resource management areas (recruitment, forms of employment, motivation, professional education, e-learning, loyalty, stress, work efficiency, MBO, perks, mobbing, professional career, derecruitment, dismissals and outplacement). Some of the questions were used to test the research thesis. 


\section{The Management by Objectives in banks in the light of empirical research ${ }^{3}$}

The results of empirical research conducted among bank employees are presented below. The first finding of the conducted research is the difference in MBO occurrence between commercial and cooperative banks. $26.3 \%$ of all respondents working in commercial banks, stated that they are part of the Management by Objectives system, whereas in cooperative banks this proportion was only 5.8\% (Table 4). The reason for such a great disparity may be the disproportionately smaller capital strength and performance of cooperative banks as compared to commercial banks (Rolski 2015, p. 256). The less wealthy cooperative banks may be characterized by the low quality of their managerial staff. It can lead to undertaking the wrong actions in the management process (The Polish Financial Supervision Authority 2015, p. 8), the use of outdated technology, low level of innovation and the lack of modernity (The Polish Bank Association 2013, p. 10).

Table 4. The Management by Objectives system according to the bank type

\begin{tabular}{|c|c|c|c|c|c|c|}
\hline & Percentage & Number of responses & Chi-square & df & Significance level & Phi Yule \\
\hline Commercial bank & $26.3 \%$ & 348 & 87.499 & 1 & 0.000 & -0.221 \\
\cline { 1 - 5 } Cooperative bank & $5.8 \%$ & 27 & & & & \\
\hline
\end{tabular}

Source: own computations based on survey data

In terms of the majority capital, one can observe prevalence in MBO's occurrence in banks with a majority foreign capital $(28.3 \%)$ (Table 5). Such a high percentage difference can be caused by the transfer of banking knowledge and the implementation of modern standards (Rzyman et al. 2015). One of these standards was MBO, successfully employed in the process of human resources management in western countries (Fulk, Bell and Bodie 2011, p. 18). Only $13.5 \%$ of the banking staff with majority domestic capital are included in the MBO system. This may be due to technological deficiency or low management culture (Dąbrowska-Gruszczyńska 2013, p. 43).

Table 5. The Management by Objectives system according to capital equity

\begin{tabular}{|c|c|c|c|c|c|c|}
\hline & Percentage & Number of responses & Chi-square & df & Significance level & Phi Yule \\
\hline Majority domestic & $13.5 \%$ & 121 & 57.788 & 1 & 0.000 & 0.182 \\
\cline { 1 - 6 } Majority foreign & $28.3 \%$ & 242 & & & & \\
\hline
\end{tabular}

Source: own computations based on survey data

The Management by Objectives is characterized by strong differentiation according to the workplace. Nearly every third respondent $(32.1 \%)$ working in the back office departments confirmed the occurrence of the MBO system in his position (Table 6). In departments having direct contact with customers (the front office), $18.1 \%$ of respondents stated that they are involved in this system. This regularity corroborates the relationships described by S. Carroll, H. Tossi (1968, p. 418) and G.H. Graham (1968, p. 297). According to their analyses, the Management by Objectives occurs more frequently at higher positions in the organizational hierarchy. Knowing the characteristics of the back office employment (Muniesa et al. 2011, p. 1193-1195), it may be assumed that majority of senior managers' work in departments of this kind.

Table 6. The Management by Objectives system according to the workplace

\begin{tabular}{|c|c|c|c|c|c|c|}
\hline & Percentage & Number of responses & Chi-square & df & Significance level & Phi Yule \\
\hline Front office & $18.1 \%$ & 200 & 36.126 & 1 & 0.000 & 0.152 \\
\hline Back office & $32.1 \%$ & 145 & & & & \\
\hline
\end{tabular}

\footnotetext{
${ }^{3}$ The empirical study data are presented in order of significance of the obtained results, with the results where the response differences were the greatest presented first.
} 
Another noticeable tendency is the increase in the occurrence of the Management by Objectives in parallel with the size of the locality where the bank is located. Towns with the population of less than 50,000 and those between 50,000 and 100,000 showed the MBO share to be $7.3 \%$ and $23.3 \%$ respectively (Table 7). Among cities of 100,000200,000 inhabitants, $25.3 \%$ of respondents declared to be covered by the Management by Objectives system. The largest MBO share was found to be in cities of 200,000-500,000 inhabitants (30.6\%) or over (31.5\%). The development, especially the quality development, of the main urban centres based on the generation and implementation of innovation technologies and making use of intellectual values, helps to create conditions conducive to the development of the human resource capital (Wrana 2013, p. 9). Big cities are seats of banks' headquarters and regional branches, which is a factor, favouring the employment of managers working by MBO principles.

Table 7. The Management by Objectives system according to the size of locality

\begin{tabular}{|c|c|c|c|c|c|c|}
\hline & Percentage & Number of respondents & Chi-square & df & Significance level & Cramér's V \\
\hline Below 50,000 inhabitants & $7.3 \%$ & 47 & \multirow[t]{5}{*}{118.482} & \multirow[t]{5}{*}{4} & \multirow[t]{5}{*}{0.000} & \multirow[t]{5}{*}{0.258} \\
\hline $50,000-100,000$ inhabitants & $23.3 \%$ & 57 & & & & \\
\hline $100,000-200,000$ inhabitants & $25.3 \%$ & 62 & & & & \\
\hline $200,000-500,000$ inhabitants & $30.6 \%$ & 38 & & & & \\
\hline over 500,000 inhabitants & $31.5 \%$ & 167 & & & & \\
\hline
\end{tabular}

Source: own computations based on survey data

A detailed gender analysis of the respondents involved in the MBO system has shown a difference of over 10.2 percentage points between females and males. Of all male respondents, $27.4 \%$ pointed to the occurrence of MBO in their workplace, while the corresponding percentage for women was 17.2\% (Table 8). The reason for such a large discrepancy is to be found in a higher number of males holding managerial positions than females (Gayle, Golan and Miller 2012, p. 831). These positions are characterized by MBO occurrence more frequently than the nonmanagerial ones. This proves the thesis that males working in banks are covered by the Management by Objectives system more often than females. U. Wilkesmann and C.J. Schmid (2012, p. 44-45) have come to similar conclusions in the course of their research. They also noticed that females under the MBO system usually pay greater attention to the proper performance of professional duties than males ${ }^{4}$.

Table 8. The Management by Objectives system according to gender

\begin{tabular}{|c|c|c|c|c|c|c|}
\hline & Percentage & Number of respondents & Chi-square & df & Significance level & Phi Yule \\
\hline Female & $17.2 \%$ & 220 & 22.410 & 1 & 0.000 & 0.113 \\
\hline Male & $27.4 \%$ & 128 & & & & \\
\hline
\end{tabular}

Source: own computations based on survey data

The percentage of young workers (under 35 years of age inclusive) covered by MBO equals 23.2\% (Table 9). Among older employees (over 35 years of age) this proportion is $17.9 \%$, the difference thus being 5.3 percentage points. Young workers frequently represent values which are the most required on the labour market. Therefore employers are doing their best to make high-flier subordinates emotionally attached to their companies (DeKay

\footnotetext{
${ }^{4}$ It is therefore odd that males hold managerial positions more frequently than females. The introduction of a new regulatory framework may be the way to cure this situation. However, J. Losak (1975, p. 10) argues against the implementation of gender parities. In his opinion, employees' performance is the sole basis for their evaluation. Determined efforts at establishing a proper balance between female and male quotas in a company could prove pernicious for the whole organization.
} 
2013 , p. 250). For that reason, with regard to these workers employers are more willing to use a wide range of motivational methods and instruments. It helps them establish and maintain mutual ties and retain young employees in the company (Kampioni-Zawadka 2014, p. 143).

Table 9. The Management by Objectives system according to age

\begin{tabular}{|c|c|c|c|c|c|c|}
\hline & Percentage & Number of respondents & Chi-square & df & Significance level & Phi Yule \\
\hline Under 35 years of age inclusive (median) & $23.2 \%$ & 221 & \multirow[t]{2}{*}{8.167} & \multirow[t]{2}{*}{1} & \multirow[t]{2}{*}{0.004} & \multirow[t]{2}{*}{-0.066} \\
\hline Over 35 years of age (median) & $17.9 \%$ & 165 & & & & \\
\hline
\end{tabular}

Source: own computations based on survey data

With regard to the criterion of education a certain asymmetry has been observed. This asymmetry relates to the level of education of employees involved in MBO. Staff with tertiary education, both graduates in Economics $(24.1 \%)$ and other majors $(21.4 \%)$, are largely covered by the system (Table 10). Only $11.4 \%$ of graduates of secondary schools of Economics declared to be working under MBO, whereas $13.7 \%$ of graduates of other schools confirm that. The Management by Objectives was not observed among the graduates of primary or vocational schools. On this basis, employees could be divided into two groups: those with a university diploma and those with secondary education. The difference between these groups in MBO occurrence may reach even $10 \%$. The results prove the thesis according to which university-educated employees are more frequently covered by the Management by Objectives system than those with a secondary school diploma. This regularity finds its reflection in the relationship described by G.H. Graham's (1968, p. 298) between the acquired education and the MBO occurrence. It can be explained by the characteristics of positions which are subject to MBO. Usually, higher organizational positions require higher professional qualifications. Therefore, employers are trying to fill these vacancies with candidates with tertiary education. Such employees, even when lacking strictly economic education, have been taught to adopt an analytical approach to problem-solving (Jepsen, Troske and Coomes 2014, p. 97). In the course of their research, D. Terpstra and P. Olson (1984, p. 439) have arrived at slightly different conclusions. They have analysed the opinions of employees working under MBO. According to their results, once the Management by Objectives system has been implemented, the employees felt that the requirements regarding their professional qualifications have been relaxed.

Table 10. The Management by Objectives system according to education

\begin{tabular}{|c|c|c|c|c|c|c|}
\hline & Criterion & Number of respondents & Chi-square & $\mathrm{df}$ & Significance level & Cramér's V \\
\hline University (major in Economics) & $24.1 \%$ & 209 & \multirow[t]{6}{*}{26.709} & \multirow[t]{6}{*}{5} & \multirow[t]{6}{*}{0.000} & \multirow[t]{6}{*}{0.121} \\
\hline University (other) & $21.4 \%$ & 108 & & & & \\
\hline High school (major in Economics) & $11.4 \%$ & 30 & & & & \\
\hline High school (other) & $13.7 \%$ & 25 & & & & \\
\hline Vocational & - & 0 & & & & \\
\hline Primary & - & 0 & & & & \\
\hline
\end{tabular}

Source: own computations based on survey data

The relationship between an employee's seniority in the current bank and MBO occurrence is very interesting. A noticeable trend is for MBO to be applied more frequently to employees with less job experience in the current workplace than the more experienced ones. The survey showed that nearly every fourth respondent (23.5\%) with up to and including 7 years' seniority with the current employer is covered by the MBO system (Table 11). Among employees with seniority of over 7 years the proportion is $17.7 \%$, the difference between both values being 5.8 percentage points. 
Table 11. The Management by Objectives system according to seniority in the current bank, in banking and in general

\begin{tabular}{|c|c|c|c|c|c|c|}
\hline & Percentage & $\begin{array}{l}\text { Number of } \\
\text { respondents }\end{array}$ & $\begin{array}{c}\text { Chi- } \\
\text { square }\end{array}$ & df & $\begin{array}{c}\text { Significance } \\
\text { level }\end{array}$ & $\begin{array}{l}\text { Phi } \\
\text { Yule }\end{array}$ \\
\hline $\begin{array}{c}\text { Up to } 7 \text { years' seniority (inclusive) with current } \\
\text { employer (median) }\end{array}$ & $23.5 \%$ & 219 & \multirow[t]{2}{*}{9.897} & \multirow[t]{2}{*}{1} & \multirow[t]{2}{*}{0.002} & \multirow[t]{2}{*}{-0.073} \\
\hline Over 7 years' seniority with current employer (median) & $17.7 \%$ & 167 & & & & \\
\hline Up to 10 years' seniority in banking (inclusive) (median) & $22.7 \%$ & 234 & \multirow[t]{2}{*}{6.601} & \multirow[t]{2}{*}{1} & \multirow[t]{2}{*}{0.010} & \multirow[t]{2}{*}{-0.059} \\
\hline Over 10 years' seniority in banking (median) & $17.9 \%$ & 152 & & & & \\
\hline Up to 12 years' combined seniority (inclusive) (median) & $23.2 \%$ & 215 & \multirow[t]{2}{*}{7.746} & \multirow[t]{2}{*}{1} & \multirow[t]{2}{*}{0.005} & \multirow[t]{2}{*}{-0.064} \\
\hline Over 12 years' combined seniority (median) & $18.0 \%$ & 171 & & & & \\
\hline
\end{tabular}

Source: own computations based on survey data

This trend was also confirmed with reference to seniority in banking. It has been observed that $22.7 \%$ of employees with up to and including 10 years' seniority in banking are covered by $\mathrm{MBO}$ as compared to $17.9 \%$ for those with over 10 years' seniority. As regards the criterion of combined tenure, $23.2 \%$ of employees with up to and including 12 years' seniority are involved in $\mathrm{MBO}$, whereas for employees with seniority of over 12 years the proportion is $18 \%$.

No significant disparities have been shown in the occurrence of the Management by Objectives with regard to job seniority (in the current workplace, in banking and combined). This confirms the relationship described by G.H. Graham in 1968 (p. 297), according to which employees with longer tenure in the current workplace are involved in the Management by Objectives system less frequently than employees with less job experience. This may result from the more experienced employees' lower awareness of the incentive system operating in their bank. On the other hand, the employer may be the one responsible. Human Resource departments feel obliged to inform the newly-employed staff about the motivational system adopted in the workplace, overlooking employees with longer seniority, taking their knowledge of the incentive system for granted. This is confirmed by the increased frequency of 'there is no such system' (or 'I know nothing about it') responses by the more experienced employees. Therefore, the thesis propounding the more frequent occurrence of MBO among employees with longer job seniority at the current workplace than among the less experienced ones has been disproved. However, this phenomenon requires further, broader and more detailed analysis.

The analysis of the Management by Objectives system in relation to the position held by the respondents showed it was more common among senior managers $(38.1 \%)$. A correspondence has been observed between the decreasing proportion of employees involved in $\mathrm{MBO}$ and their position in the organizational hierarchy. Accordingly, the proportion of middle management staff covered by $\mathrm{MBO}$ is $24.6 \%$, compared to $23.6 \%$ for lower-level managers and $19.7 \%$ for non-managerial staff. This trend is also confirmed by the specialist literature. Unfortunately, the statistical significance of this analysis (15\%) does not meet the statistical significance level of 5\% determined for social sciences (Hansen, Lunde and Nason 2005, p. 11). Additionally, it was observed that the occurrence of sales promotion systems decreases with positions at the top of the hierarchy. Lower-level managers (63.5\%) and nonmanagement employees (58\%) are covered by sales-oriented systems more frequently than others. This stands in contrast to $\mathrm{MBO}$ distribution.

\section{Conclusions}

The following conclusions can be drawn from the above analysis: the first thesis propounding the segmentation of banks in Poland according to the Management by Objectives system was confirmed by the conducted study. The observed differences varied in intensity. There were both major differences relating to the kind of bank (commercial vs. cooperative; majority domestic vs. majority foreign capital) and minor ones, such as the age of employees 
embraced by MBO. The second thesis concerned the job positions covered by MBO and assumed that the managerial staff are subject to MBO more frequently than the non-managerial employees. This thesis was proved to be correct. However, in this case the significance level exceeded 5\%. The third thesis was relating to more frequent MBO occurrence among employees with longer job seniority in the current workplace than among people at the beginning of their employment in a particular unit. The study results disproved this thesis statement. As it turned out, employees with shorter seniority are involved in the MBO system more frequently than others. The last two these have been proved true. A detailed analysis has confirmed that male employees in banks are covered by the Management by Objectives system more frequently than females. The last thesis postulating that bank staff with tertiary education are subject to the Management by Objectives more often than employees with secondary education has been proved true.

One could put forward a number of recommendations regarding the system of Management by Objectives. One issue which needs to be changed is the Human Resource management in cooperative banks and banks with majority domestic capital. They use outdated HR management techniques and, consequently, are not able to exploit fully the potential of their employees. In their case, MBO may turn out to be a useful tool. Another area which requires change is the approach to MBO. It so happens that Human Resource managers attempt to introduce other modified systems under the disguise of MBO. These often have hardly anything in common with the general assumptions of the system as recommended by P.F. Drucker and as such do nothing to improve the system of management. Such practices lead to the negative reputation that the system of Management by Objectives has undeservedly acquired.

These considerations leave ample room for further analyses. An interesting area of detailed research could deal with the perception of the MBO system by the employees themselves. It could include the assessment of the system in relation to the kind of position held by the respondent. A comparison of an organization's financial results prior to and after the introduction of MBO would also make an interesting object of study.

\section{References}

Belás, J.; Korauš, M.; Kombo, F.; Korauš, A. 2016. Electronic banking security and customer satisfaction and in commercial banks, Journal of Security and Sustainability Issues 5(3): 411-422. http://dx.doi.org/10.9770/jssi.2016.5.3(9)

Barska, A.; Łychmus, P. 2007. The importance of climate work in creating the image of the company, in Bartkowiak, G.; Balewski, B. (Ed.). HRM in Poland. Chances and dangers. Zielona Góra: Western School of International Trade and Finance name of John Paul II, 39-47.

Baxter, J.; Wright, O. E. 2000. The Glass Ceiling Hypothesis. A Comparative Study of the United States, Sweden, and Australia, Gender \& Society 14(2): 275-294 Available on the Internet: <https://www.ssc.wisc.edu/ wright/GenderGap.pdf>.

Bieniok, H. 2001. Methods for efficient management. Warsaw: Agencja Wydawnicza "Placet".

Blikle, A. 2014. Quality doctrine. The thing about effective management. Warsaw: Helion. Available on the Internet: <http://www.moznainaczej.com.pl/Download/DoktrynaJakosci/DoktrynaJakosci.pdf>.

Bondaryeva, I. A.; Kravchenko, S. I.; Mieshkov, A. V. 2015. Features of The Investment and Innovative Orientation in Students` Training in Technical Higher Educational Institution (on the Example of Donetsk Region), Naucno-tehniceskie vedoomosti SPBGPU.

Ekonomicieskie nauki 4(223): 236-244.

Chrościcki, Z. 1999. Management of the company. Selected issues. Warsaw: C.H. Beck.

Čiutienè, R.; Petrauskas, P. 2012. Management by Objectives Using Coaching, Economics \& Management 17(4): 1559-1563.

Dąbrowska-Gruszczyńska, K. 2013. Foreign capital in the Polish banking sector and the level of its development compared to OECD countries, Economic Studies, Scientific Papers of the University of Economics in Katowice 170: 43-58. 
DeKay, S. 2013. Engaging and Motivating Employees and Students: The Search for a Psychological Grail? Business Communication Quarterly 76(2): 249-251.

Drucker, P. F. 1994. Management practice. Cracow: Akademia Ekonomiczna w Krakowie.

Fulk, H. K.; Bell, R. L.; Bodie, N. 2011. Team Management by Objectives: Enhancing Developing Teams' Performance, Journal of Management Policy \& Practice 12(3): 17-26.

Fuschi, D.L.; Tvaronavičienè M. 2014. Sustainable development, Big Data and supervisory control: service quality in banking sector, Journal of Security and Sustainability Issues 3(3): 5-14. DOI: http://dx.doi.org/10.9770/jssi.2014.3.3(1)

Gayle, G. L.; Golan, L.; Miller, R. A. 2012. Gender Differences in Executive Compensation and Job Mobility, Journal of Labor Economics 30(4): 829-871.

Graham, G. H.; 1968. Correlates of Perceived Importance of Organizational Objectives, Academy of Management Journal 11(3): 291-300.

Hansen, P. R.; Lunde, A.; Nason, J. M. 2005. Testing the Significance of Calendar Effects, Working Paper Series (Federal Reserve Bank of Atlanta) 2005(2): 1-29.

Jepsen, C.; Troske, K.; Coomes, P. 2014. The Labor-Market Returns to Community College Degrees, Diplomas, and Certificates, Journal of Labor Economics 32(1): 95-121.

Kalinowska-Sufinowicz, B. 2005. Women's discrimination on the Polish labor market. Poznań: Wydawnictwo Uniwersytetu Ekonomicznego w Poznaniu.

Kampioni-Zawadka, M. 2014. Talent management in contemporary organizations, Scientific Papers of the Wroclaw University of Economics Iss. 349: 140-151.

Kaźmierczyk, J. 2011. Technological and socio-economic determinants of employment in the banking sector in Poland. Warsaw: CeDeWu.

Kaźmierczyk, J.; Świt, M. 2011, The Importance Of Ethic In The Sphere Of Employment in Polish Banking Sector, International Conference on Eurasian Economies: 299-305.

Lederer, A. L.; Burky, L. B. 1988. Understanding Top Management's Objectives: A Management Information Systems Concern, Journal of Information Systems 3(1): 50-66.

Liu, X. 2010. On Application of MBO in College Management, International Education Studies 3(2): 219-223.

Losak, J. 1975. The Myth of Rational Evaluation, Annual Meeting of the American Association of Community and Junior Colleges. April 1316, Seattle, Washington, USA. Available on the Internet: 〈http://files.eric.ed.gov/fulltext/ED112993.pdf>.

Luft, S. 2014. A MBO Case Study on LI, Supervision 75(3): 23-26.

Muniesa, F.; Chabert, D.; Ducrocq-Grondin, M.; Scott, S. V. 2011. Back-Office Intricacy: The Description of Financial Objects in an Investment Bank, Industrial and Corporate Change 20(4): 1189-1213.

Olexandrivna, Y. N. 2016. Strategic Management by Balanced Development: Meaning, Economic Processes Management Iss. 1: 63-69.

Omran, M. S.; Alizadeh, H.; Esmaeeli, B. 2015. The analysis of glass ceiling phenomenon in the promotion of women's abilities in organizations, International Journal of Organizational Leadership 4(3): 315-323.

Razminienè, K.; Tvaronavičienė, M.; Zemlickienė, V. 2016. Evaluation of cluster efficiency tool, Terra Economicus 14(3): 101-111. DOI: http://dx.doi.org/10.18522/2073-6606-2016-14-3-101-111

Reinfuss, R. 2009. MBO simple and effective technique of managing of your business. Gliwice: Helion.

Rolski, M. 2015. Cooperative banks in Poland - private property in the service of the local community or business for profit?, Scientific Papers of the Wroclaw University of Economics Iss. 403: 265-274. 


\section{The International Journal}

ENTREPRENEURSHIP AND SUSTAINABILITY ISSUES

ISSN 2345-0282 (online) http://jssidoi.org/jesi/ 2016 Volume 4 Number 2 (December)

Romashkina, G. F.; Andrianova E. V. 2007. Job motivation: ideal models and behawiour, Proceedings of the Ural Federal University. Social Sciences 51.3: 50-55.

Rzyman, K.; Zadrożna, S.; Golonko, J.; Raszkowska G. 2015. Banki w Polsce znów będa polskie?, Polskie Radio. Available on the Internet: <http://www.polskieradio.pl/42/4393/Artykul/1527244,Banki-w-Polsce-znow-beda-polskie>.

Terpstra, D. E.; Olson, P. D. 1984. Sources of Resistance to Management-by-Objectives Among University Faculty, Education 104(4): 435443.

The Polish Bank Association. 2013. Bank monitor, May 2013. Warsaw. Available on the Internet: <https://zbp.pl/public/repozytorium/Menu_gorne/Raporty/Monitor/MB_0513_z_komentarzem.pdf>.

The Polish Financial Supervision Authority. 2015. Information about the situation of cooperative banks and associations in 2014. Warsaw. Available on the Internet: 〈http://www.knf.gov.pl/Images/Informacja_o_sytuacji_bankow_spoldzielczych_2014_tcm75-41491.pdf〉.

Tosi, H. L.; Carroll, S. J. 1968. Managerial Reaction To Management By Objectives, Academy of Management Journal 11(4): 415-426.

Tvaronavičienè, M.; Černevičiūtè, J. 2015. Technology transfer phenomenon and its impact on sustainable development, Journal of Security and Sustainability Issues 5(1): 87-97. http://dx.doi.org/10.9770/jssi.2015.5.1(7)

Voronov, V.; Lavrinenko, O. J.; Stashane, J. V. 2014. Ocenka dynamiki mezregionalnyh razlicij (Evropejskim opyt), Sociologicieskie issledovanija 1: 29-39.

Wilkesmann, U.; Schmid, C. J. 2012. The impacts of new governance on teaching at German universities. Findings from a national survey, Higher Education: The International Journal of Higher Education and Educational Planning 63(1): 33-52.

Wrana, K. 2013. Conditions and processes of urban development, Silesian Regional Studies 4. Available on the Internet: <http://ssr.slaskie.pl/zalaczniki/2013/12/19/1387443425.pdf>.

Wyrwa, J. 2015. Organizational restructuring as a way of counteracting a crisis in an enterprise, Scientific Journal of Polish Economic Society in Zielona Góra 2: 127-143.

Korauš, A.; Dobrovič, J.; Ključnikov, A.; Gombár, M. 2016. Consumer approach to bank payment card security and fraud, Journal of Security and Sustainability Issues 6(1): 85-102. http://dx.doi.org/10.9770/jssi.2016.6.1(6)

Jerzy KAŹMIERCZYK (PhD) is a Postdoc at Tyumen State University and Assistant Professor at Poznan University of Economics and Business, Member of the Research Council of Polish Economic Society, Member of the Presidium and Board of Polish Economic Society Zielona Gora and Member of the Regional Labour Market Board at Lubuskie Marshal's Office. He is currently editing an issue of Studia Oeconomica Posnaniensia and issue of Scientific Journal of Polish Economic Society in Zielona Gora. Research interests: labour market, HRM, banking, macroeconomics.

ORCHID ID: orcid.org/0000-0002-5976-0210

Mateusz APTACY is a graduate of Poznan University of Economics and Business and practitioner of HRM in banking. Research interests: Management by Objectives, Human Resources Management, labour market.

Copyright (C) 2016 by author(s) and VsI Entrepreneurship and Sustainability Center This work is licensed under the Creative Commons Attribution International License (CC BY). http://creativecommons.org/licenses/by/4.0/ 